\title{
Early Middle Pleistocene sediments at Sidestrand, northeast Norfolk, yield the most extensive preglacial cold stage beetle assemblage from Britain.
}

\author{
Nigel R. Larkin ${ }^{1 *}$, G. R. Coope ${ }^{2+}$, Jonathan R. Lee ${ }^{3}$ and Barbara Silva4 \\ ${ }^{1}$ Natural History Department, Norwich Castle Museum, Market Avenue, Norwich, Norfolk, NR1 3JQ, UK. \\ Email: nrlarkin@easynet.co.uk \\ 2 Tigh-na-cleirich Foss, Near Pitlochry, Pertshire. PH16 5NQ, UK. \\ 3British Geological Survey, Keyworth, Nottingham, NG12 5GG, UK. \\ 4 Department of Geography, Royal Holloway University of London, Egham Hill, Egham, TW20 oEX, UK. \\ *Corresponding author \\ + Now deceased
}

\begin{abstract}
Fluvial sediments (Cromer Forest-bed Formation) at Sidestrand, northeast Norfolk, have yielded the most extensive preglacial early Middle Pleistocene cold (arctic) stage beetle assemblage known from Britain. The assemblage is composed of 59 taxa indicating severely cold and continental climatic conditions. Mutual Climatic Range reconstructions suggest that the mean temperature of the warmest month (July) was between $10^{\circ} \mathrm{C}$ and $13^{\circ} \mathrm{C}$ and the mean temperature of the coldest months (January and February) between $-17^{\circ} \mathrm{C}$ and $-10^{\circ} \mathrm{C}$, although the actual palaeotemperatures were probably towards the lower end of these ranges. Associated pollen and macroflora remains were poorly represented but all are known from other cold stage contexts. Excavations reveal that this freshwater arctic assemblage occurs within units between two important stratigraphic marker horizons, the Sidestrand Hall Member of the Cromer Forest-bed Formation and the first lowland glacigenic deposit (Happisburgh Till Member) in eastern England, although the ages of both remain equivocal. Recent amino-acid chronologies of molluscan faunas from the Sidestrand Hall Member indicate a MIS 13 age, with by inference, a MIS 12 age for the overlying arctic units with cold beetle fauna and for the Happisburgh Till Member. However, the arctic units are separated from the two stratigraphic marker horizons by shallow marine deposits (Wroxham Crag Formation) demonstrating at least two intervening phases of marine transgression and a cold climate marine regression. The climatic significance of these marine transgressions and their chronostratigraphic implications are currently uncertain.
\end{abstract}

Keywords: early Middle Pleistocene, arctic assemblage, Coleoptera

\section{Introduction}

Much of our current understanding of Quaternary climates within Britain stems principally from studies focusing upon the last 450,000 years which span the late Middle Pleistocene to the Holocene. Climate was regulated during this interval by extreme glacial- and interglacial-stage oscillations driven by the $100 \mathrm{ka}$ Milankovitch (eccentricity) cycles (Imbrie et al., 1984; Lisiecki and Raymo, 2007) and smaller 'subMilankovitch' variations linked to ice mass-oceanic circulation feedback processes. Collectively, they resulted in high magnitude changes in climate and environment and 
corresponding variability in sea-levels, biomass productivity, geological processes and sediment budgets that can be observed in detail within the British Quaternary record (Candy et al., 2010).

By contrast, comparatively less is known about climates that prevailed during the preceding parts of the British Quaternary record due to the more fragmented nature of the geological evidence and limited ability of applying robust absolute and relative chronological frameworks (Rose, 2009; Candy et al., 2010). Nevertheless, understanding the climates of this interval is important to understanding the dispersal of early humans and the long-term development of cold climates and glaciation within Britain (Rose, 2009; Candy et al., 2010; Lee et al., 2011; Ashton and Lewis, 2012; Parfitt et al., 2010a; Preece et al, 2009). Currently, isotope records of ice volume, coupled with records of ice rafted debris plus onshore and offshore evidence for glaciation, portray a highly-dynamic climatic picture within the North Atlantic region and adjacent areas, characterised by the progressive intensification of the climatic signature coupled with the step-wise up-ramping in the scale and magnitude of glaciation (Flesche Kleiven et al., 2002; Mudelsee and Raymo, 2005; Knies et al., 2009; Böse et al., 2012; Lee et al., 2012; Thierens et al., 2012). Within northern Europe the early Middle Pleistocene includes the 'Cromerian Complex' (c.0.9-0.48 Ma) which in Britain is characterised by multiple temperate and cold climatic events depicted within the geological record by complex patterns of sea-level change, soil development, river behaviour and flora and fauna (Kemp et al., 1993; Murton et al., 1995; Preece and Parfitt, 2000, 2012; Lee et al., 2006; Rose, 2009; Candy et al., 2010). Critically, early Middle Pleistocene climates have been shown to range between warm (Mediterranean to temperate) and cold (periglacial to boreal) climate extremes (Candy et al., 2006, 2010). Whilst it is known that climates were sufficiently cold and wet to enable localised ice cap development in highland areas of Britain and Ireland throughout large parts of the early Middle Pleistocene (Lee et al., 2011, 2012; Bose et al., 2012; Thierens et al., 2012) there is generally a paucity of qualitative and quantitative climatic data during this time-interval.

Within this paper, we aim to contribute to improving the understanding of early Middle Pleistocene climates within Britain by describing the sedimentology, floral (pollen) and faunal (Coleoptera) evidence from a site in northern East Anglia, UK.

\section{Site and geological context}

This investigation is centered upon cliff sections and beach excavations at Sidestrand, situated approximately $4.5 \mathrm{~km}$ to the southeast of Cromer in northeast Norfolk, Britain (National Grid Reference: TG 262,401, Fig 1). The Quaternary geology of the locality encompasses a thick (up to $60 \mathrm{~m}$ ) glacigenic sediment pile of early to late Middle Pleistocene age comprising several tills and intervening glaciolacustrine and outwash deposits (Hart, 1990, 1992; Lunkka, 1994; Lee, 2001; Lee et al., 2004a, 2013). These overlie up to $10 \mathrm{~m}$ of preglacial sands, gravels, clays and peats (West, 1980; Green and McGregor, 1990; Briant et al., 1999; Lee, 2009; Preece et al., 2009) that have been in-part glacitectonised causing localised remobilisation (Lee, 2009) and rafting (Burke et al., 2009; Vaughan-Hirsch et al., 2013). Preglacial sediments in north Norfolk can be delineated based upon their genesis into shallow marine / coastal (Crag Group) and freshwater deposits (Cromer Forest-bed Formation) that relate to a 'northern river' that drained into the area from central England (Rose et al., 2001). The Crag Group itself can be sub-divided into several different formations including the Wroxham Crag Formation of late Early and early Middle Pleistocene age, and a lower Sidestrand Member (formerly the 'Weybourne Crag') which forms part of the Early Pleistocene Norwich Crag 
Formation. There is relatively common evidence for the existence of cold climates during the deposition of the Crag Group (Candy et al., 2010). These include horizons of periglacial structures such as ice wedge casts which form ephemeral land-surfaces (West, 1980; Fish et al., 1998; Briant et al., 1999; Whiteman, 2002; Lee et al., 2003; Larkin et al., 2011); discrete horizons of ice-rafted erratics relating to early phases of glaciation adjacent to the North Sea Basin (Larkin et al., 2011); and cold climate floras and faunas (Funnell and West, 1962; Norton, 1967; West, 1980).

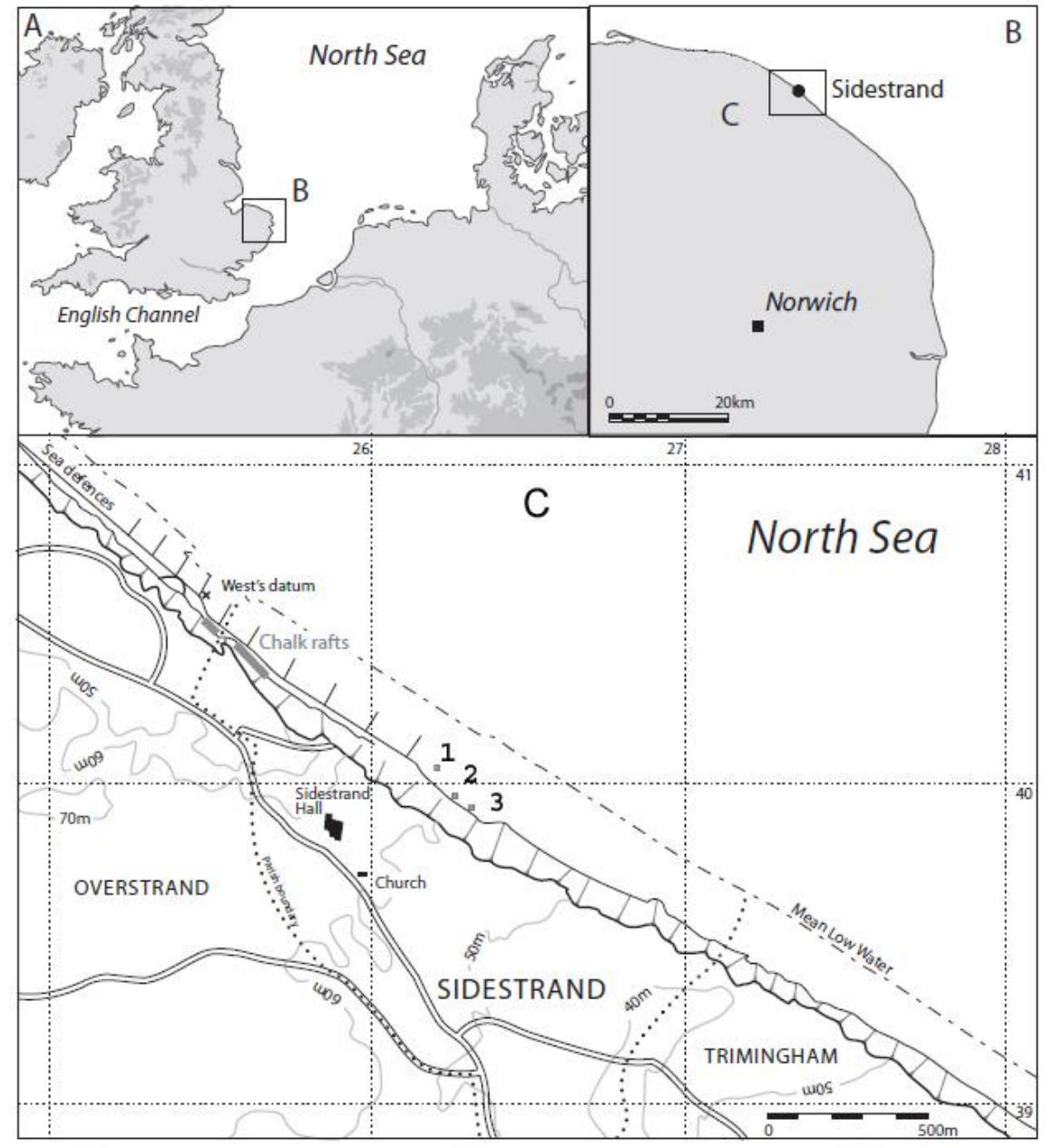

Fig. 1. The locations of Sample Sites 1, 2 and 3 described below.

\section{Methodology}

\subsection{Overview of analytical techniques}

Temporary exposures of dark grey organic-rich laminated silts, fine sands and stratified sands and silts either within cliff sections or on the foreshore were examined during fieldwork undertaken in 2007 (Fig. 2) and 2010 (Figs. 3 and 4). Exposures were excavated by hand and carefully examined to ensure that outcrops could be correlated laterally and vertically with each other and, where possible, to key stratigraphic markers within the Sidestrand preglacial sequences. Bulk samples were collected from excavations for analysis of the plant macrofossil, pollen and Coleoptera assemblages. 
Coleoptera were extracted using the standard method described by Coope (1986). The organic material readily broke down in water and the resultant slurry was then washed over a sieve with $300 \mu \mathrm{m}$ mesh aperture. The material held on the sieve was then subjected to flotation techniques which concentrate the insect remains. These were then sorted from the plant debris under a binocular microscope and the fossil Coleoptera were stored in tubes of dilute alcohol (c. 40\%).

Pollen samples were prepared for analysis using a modified version of Moore et al. (1991) in a clean laboratory environment. Samples were dispersed and spiked with an 'exotic', dispersed using sodium pyrophosphate, and sieved through a coarse $(212 \mu \mathrm{m})$ and fine $(5 \mu \mathrm{m})$ sieve. The samples were floated using sodium polytungstate and mounted onto microscope slides, unstained, using glycerol jelly. The pollen grains and spores were counted using an Olympus $\mathrm{CH}-2$ transmitted light microscope.

Plant macrofossil samples were prepared for identification by disaggregating in warm water, and then washing through a nest of sieves down to the $125 \mu \mathrm{m}$ mesh. Macroscopic plant remains were picked under a low power binocular microscope. Identification was based upon reference floras and comparison with modern reference material.

\subsection{Description of sample locations}

\subsubsection{Sample Site 1 (2nd October 2007; Grid ref. TG 2625 4010)}

Sample Site 1 represents a small exposure that was observed on the beach foreshore (Figs. 2 and 5). The $1.2 \mathrm{~m}$ long section revealed approximately $0.25 \mathrm{~m}$ of dark grey laminated organic silt and fine sand (Unit 1A) punctuated by a thin $(0.1 \mathrm{~m})$ lens of organic material that contained wood fragments and plant macroflora. Changes between organic silt and fine sand laminae record cyclical variations in energy regime and sediment supply within a low-moderate energy depositional environment. The organic content of the silt laminations and the lens containing coarse organic material indicates the close proximity of the site to a biomass source. A bulk sample (Sample 1) of c. $8 \mathrm{~kg}$ was taken from this organic unit for analysis

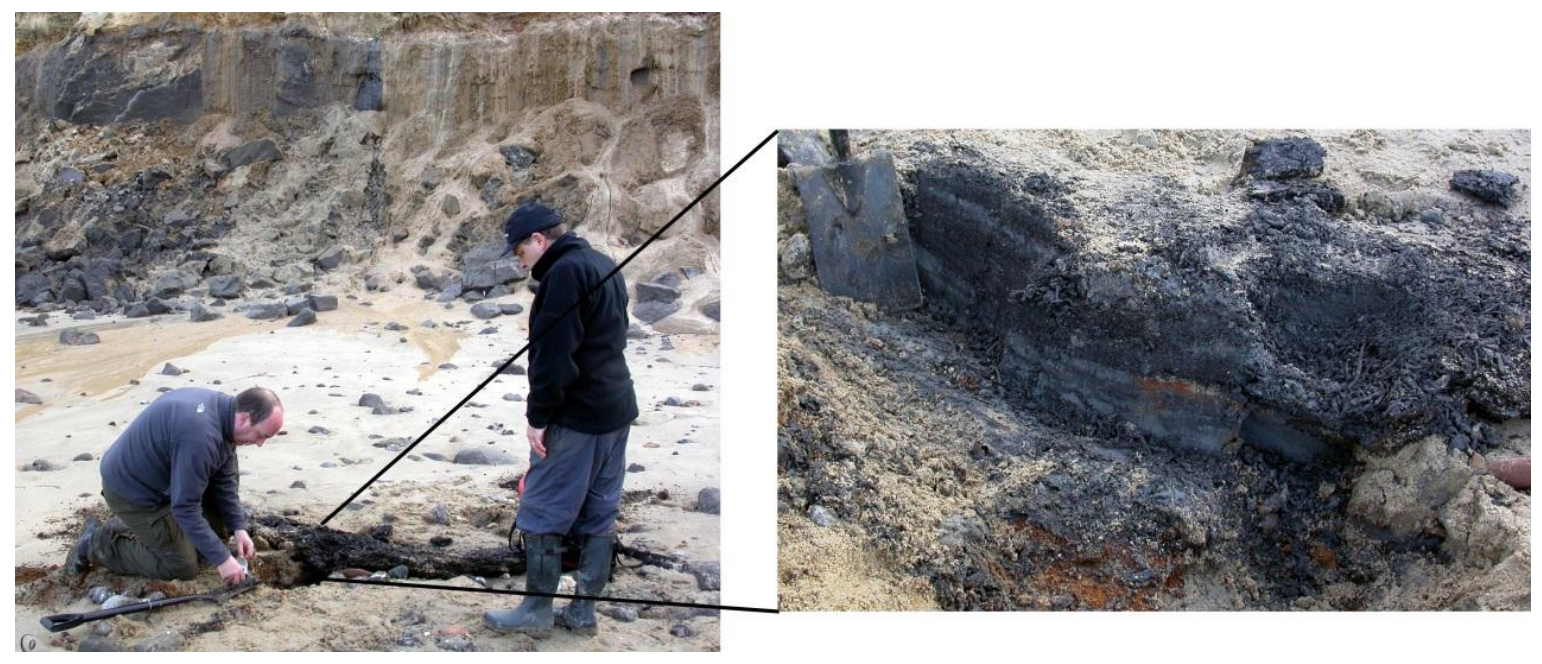

Fig. 2. The naturally-exposed Sample Site 1 at Sidestrand in October 2007. Left, the in situ cliff section in the background partially covered with clifffall. Right, detail of the macroflora-rich exposure in situ cleaned and ready for sampling (Sample 1). 


\subsubsection{Sample Site 2 ( $2^{\text {nd }}$ February 2010 ; Grid ref. TG 26303995$)$}

Sample Site 2 comprises a $1.9 \mathrm{~m}$ high excavated section that can be sub-divided into five units (Figs. 3 and 5). Unit $2 A$ at the base of the section is $0.85 \mathrm{~m}$ thick and comprises pale grey rippled silty sands with occasional silt and clay lenses (flasers) that record sedimentation under fluctuating energy conditions. They pass upwards into 0.15 $\mathrm{m}$ thick beds which exhibit low-angle trough cross-bedding sand with organic (floral) material preserved on the surfaces of the foresets. This cross-bedding records the migration of small lunate bedforms with the preservation of organic matter upon the foresets suggesting an adjacent source of flora. Unit $2 B$, upto $0.05 \mathrm{~m}$ thick, is composed of a coarse gravel erosional lag that truncates underlying Unit $2 A$. Unit $2 C$ rests conformably upon Unit $2 A$ and consists of planar cross-bedded medium-grained sands that reflect the migration of small subaqueous bedforms. These sands are overlain by a thin $0.05 \mathrm{~m}$ to $0.25 \mathrm{~m}$ bed (Unit $2 D$ ) of contorted bluish grey organic sandy silt. The upper and lower contacts of this unit are highly-irregular exhibiting flame-like and wispy contacts indicating elevated porewater content upon deposition. The sandy (coarse to fine) silty texture of the sediment suggests that deposition was rapid and associated with a relative energy shut-down. They are overlain in-turn by up to $0.5 \mathrm{~m}$ of rhythmicallylaminated sands and silts (Unit 2E) that record regular cyclical fluctuations in energy regime and sediment supply. Sample 2 (c. $2 \mathrm{~kg}$ ) was taken from the base of Sample Site 2 within Unit $2 A$.

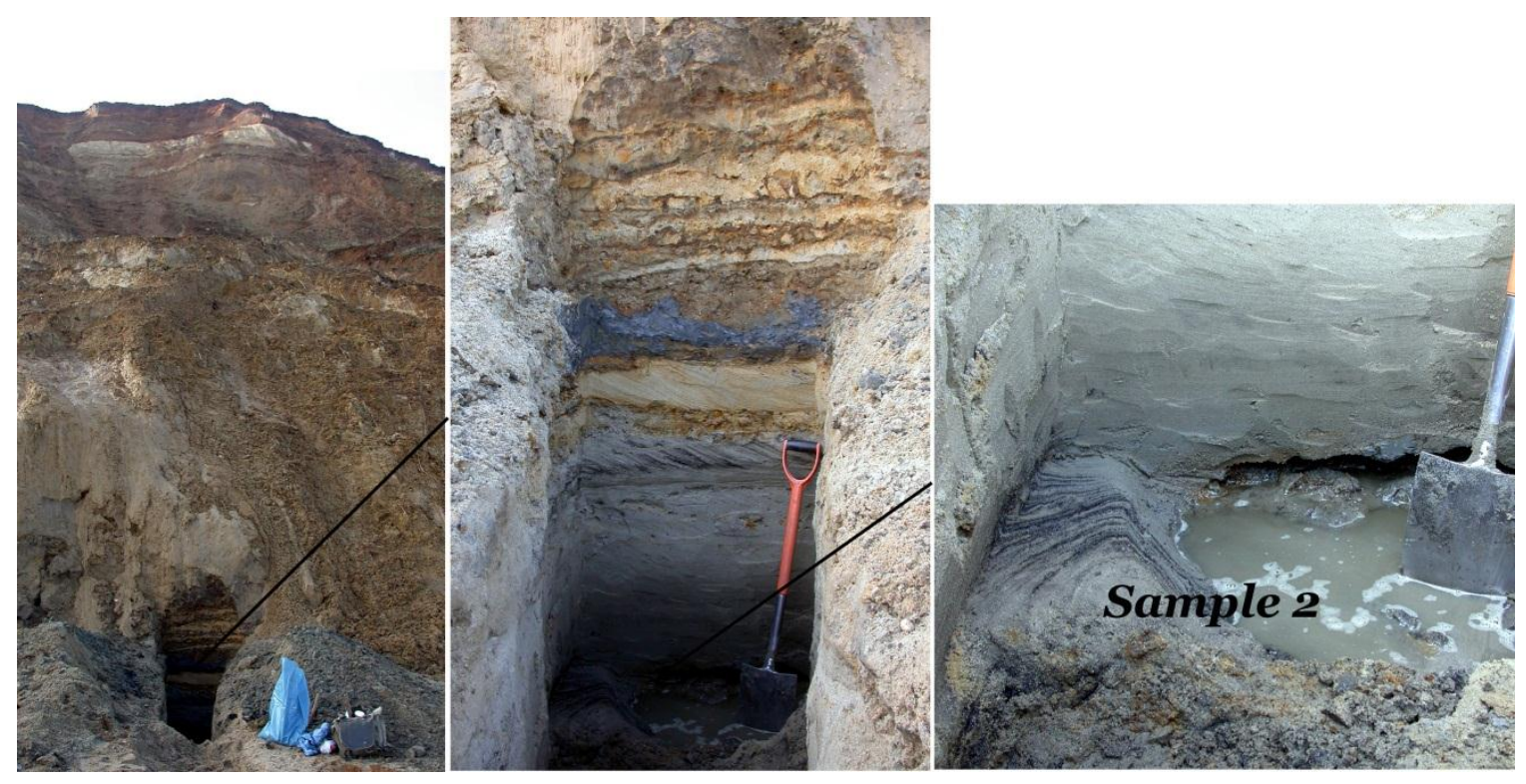

Fig. 3. Sample Site 2: Left, the context of the excavation at the base of the Sidestrand cliff. Middle, the excavation with spade for scale. Right, detail of the base of the excavation, showing the fine layers of Unit 2A that was sampled (Sample 2). 


\subsubsection{Sample Site 3 ( $3^{\text {rd }}$ March 2010; Grid ref. TG 2640 3990)}

Sample Site 3 comprises an excavation $2.5 \mathrm{~m}$ high by $1.5 \mathrm{~m}$ wide showing a sequence that can be sub-divided into five units (Units $3 A-3 E$ ) (Figs. 4 and 5). Unit $3 A$ occurs at the base of the excavation although its base was obscured by modern beach material. It comprises $0.3 \mathrm{~m}$ of rippled sand with occasional silt flasers passing upwards into planar cross-bedded sand and gravel. Bedding foresets are upto 0.05 $\mathrm{m}$ height and plunge towards the northwest. Rippled sands and silt flasers indicate frequent changes in the mode sedimentation and energy regime between moderate-high energy bedload deposition (sand ripples) to suspension-settling (silts) under low-energy conditions. The cross-bedded sands and gravels record the migration of small subaqueous bedforms under a high flow regime. Unit $3 B$ conformably overlies Unit $3 A$ and forms a $0.26 \mathrm{~m}$ thick unit of massive bluish grey organic sandy silt. The diverse grain size distribution dominated by the coarse-medium-fine sand and silt fractions, implies that sedimentation was rapid and associated with a sudden energy shut-off enabling all particle size to be deposited en mass. Unit $3 C$ lies conformably upon underlying Unit $3 B$ and forms a 1.26 $\mathrm{m}$ thick assemblage of deformed silt and sand laminations. Individual silt and sand laminations record cyclic fluctuations in energy regime and switches between finegrained suspension settling (silts) and deposition from bedload (sand). Overall, there is an upwards thickening of silt relative to sand laminae indicating an increased influence of low-energy sedimentation. Laminae within this unit are intensely contorted by a range of syn-sedimentary deformation structures that include ball-and-pillow structures, disharmonic folding and flame structures. This style of soft sediment deformation is consistent with deformation caused by sediment loading and indicates rapid deposition and high sedimentation rates.

The contact between Unit $3 C$ and Unit $3 D$ is non-conformable with Unit $3 D$ forming a 0.1-0.2 $\mathrm{m}$ thick lens which truncates bedding within the underlying unit. The sediment lens is composed of a matrix-supported diamicton which exhibits a silty clay matrix texture containing small rounded flint pebbles plus marine molluscs (Fig. 4) including Arctica islandica and Macoma obliqua (many fragmented but some complete with their valves still united). The lens exhibits variably-diffuse and flame-like margins with occasional highly-folded (disharmonic) and wispy fine sand inclusions indicative of soft-sediment deformation driven by elevated porewater content. Unit $3 D$ is truncated in-turn by up to $0.8 \mathrm{~m}$ of massive to faintly-laminated dark grey organic silty clay (Unit $3 E$ ) with occasional lens-shaped beds of clast-supported gravel and a horizon of slightly mottled bluish-grey silty clay. The faintly-laminated organic silty clay represents low energy subaqueous sedimentation in close-proximity to a biomass source whereas the slightly mottled horizon of bluish-grey silty clay, which separates two beds of organic silty clay, is interpreted as a gleyed soil horizon. The basal contact of Unit $3 E$ is sharp, gently convex-shaped and truncates Units $3 D$ and $3 C$. Small attenuated and wispy lenses of dark grey clay containing fragmented shell (i.e. Unit $3 D$ ) and fine sand (i.e. Unit $3 C$ ) occur within the basal $0.1 \mathrm{~m}$ of Unit $3 E$ and these are bound by discrete detachment planes that are aligned sub-parallel to the basal contact. The internal structure and nature of the basal contacts of Units $3 D$ and $3 E$ - including the detachment planes, attenuated lenses and soft sediment deformation, collectively suggest that these units have been remobilized and their current stratigraphic position may be of tectonic rather than sedimentary origin.

A sample (Sample 3) of about $1.5 \mathrm{~kg}$ was taken from Unit $3 B$ situated 1.26 to 1.52 $\mathrm{m}$ below the base of Unit 3D. A further sample (Sample 4) of about $1.5 \mathrm{~kg}$ was taken from 
Unit $3 A$ which contains thin lenses (flasers) of dark grey fine organic silt. This was approximately 1.60 to $1.80 \mathrm{~m}$ below the base of Unit $3 D$.

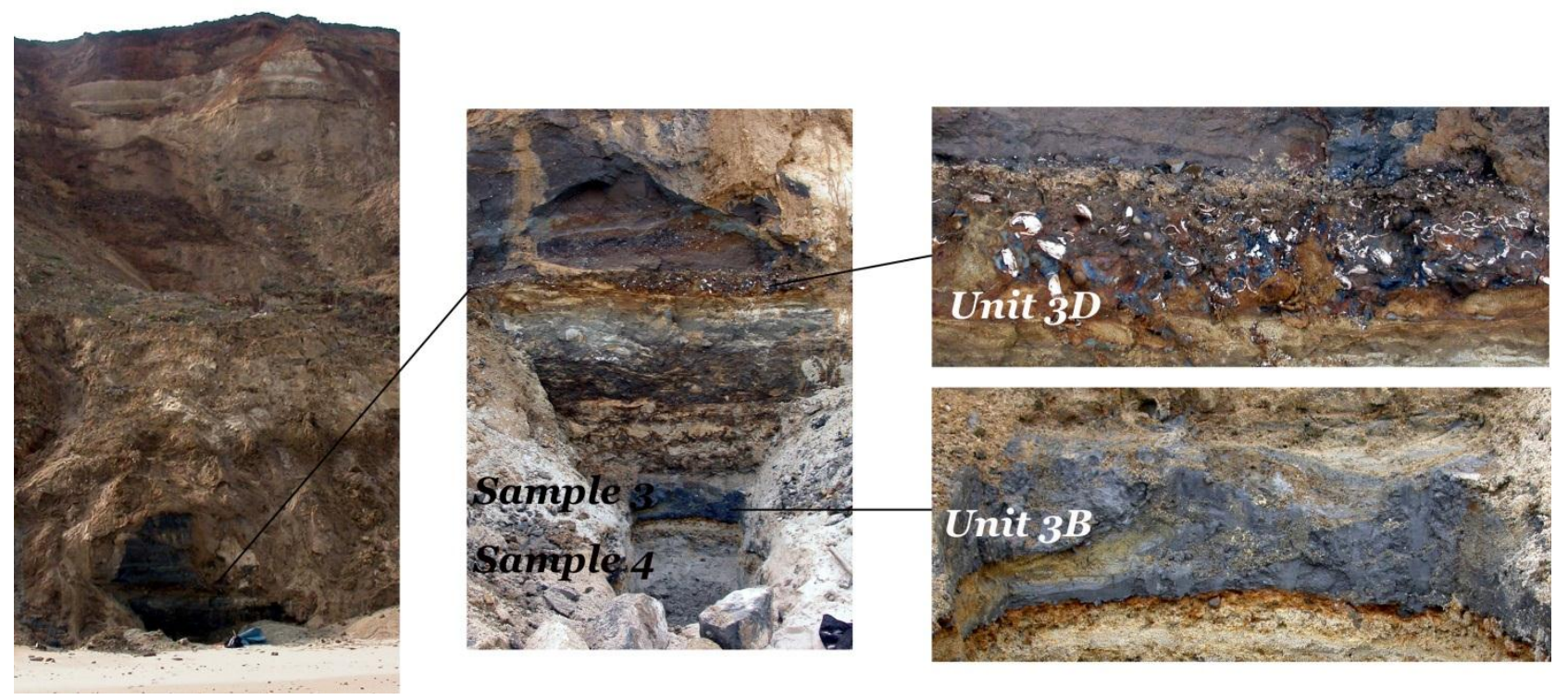

Fig. 4. Sample Site 3. Left, the context of the excavation at the base of the cliff. Middle, the excavation with the Arctica islandica / Macoma obliqua bed (Unit $3 D$ ) near the top and the layers from which samples 3 and 4 were taken lower down (from Units $3 B$ and 3 A respectively). Top right, detail of the Arctica islandica / Macoma obliqua bed. Bottom right, the distinctive layer (Unit $3 B$ ) from which sample 3 was taken.

\section{Correlation and genetic interpretation of the sample sites}

The temporary sections exposed and excavated on the foreshore and in the cliffs at Sidestrand contain a tripartite succession revealing marked changes in the style of sedimentation (Fig.5).

The base of the observed sequence comprises probable fluviatile deposits. Unit $1 A$ and the basal horizons of Unit $2 A$, composed of laminated organic silts and sands plus the lens of coarse organic material are interpreted as being deposited within a distal but active channel area of a vegetated river catchment (Miall, 1996). Individual sand laminae were probably deposited during higher-flow stages with organic silt laid-down during quieter energy conditions. The coarse organic lens was probably washed into the river and was rafted downstream before grounding. These units grade upwards into Units $2 A$ and $3 A$ comprising rippled sands with occasional silt flaser beds. The switch to sanddominated deposition demonstrates an increase in energy regime and sediment supply. Silt flasers point to deposition within a point bar or an ephemeral channel inundated during a series of flood events (Bhattacharya, 1997; Martin, 2000). Unit $2 A$ is in-turn truncated by a thin gravel lag (Unit $2 B$ ) and cross-bedded sands (Unit $2 C$ ). These units are interpreted as recording active channel migration and scouring across the site with firstly the deposition of the gravels (Unit $2 B$ ) and then the sands as small migrating subaqueous bedforms. They are overlain by Unit $2 D$ which can be correlated with Unit $3 B$ between Sample Sites 2 and 3. Both units are composed of largely massive organic sandy silt with the sand fraction including significant coarse, medium and fine proportions. This particle size distribution implies that deposition occurred from rapid 
flow-deceleration of a sediment-laden water column. One possible interpretation is that sedimentation occurred during the flooding of an overbank area (Fielding, 1986).

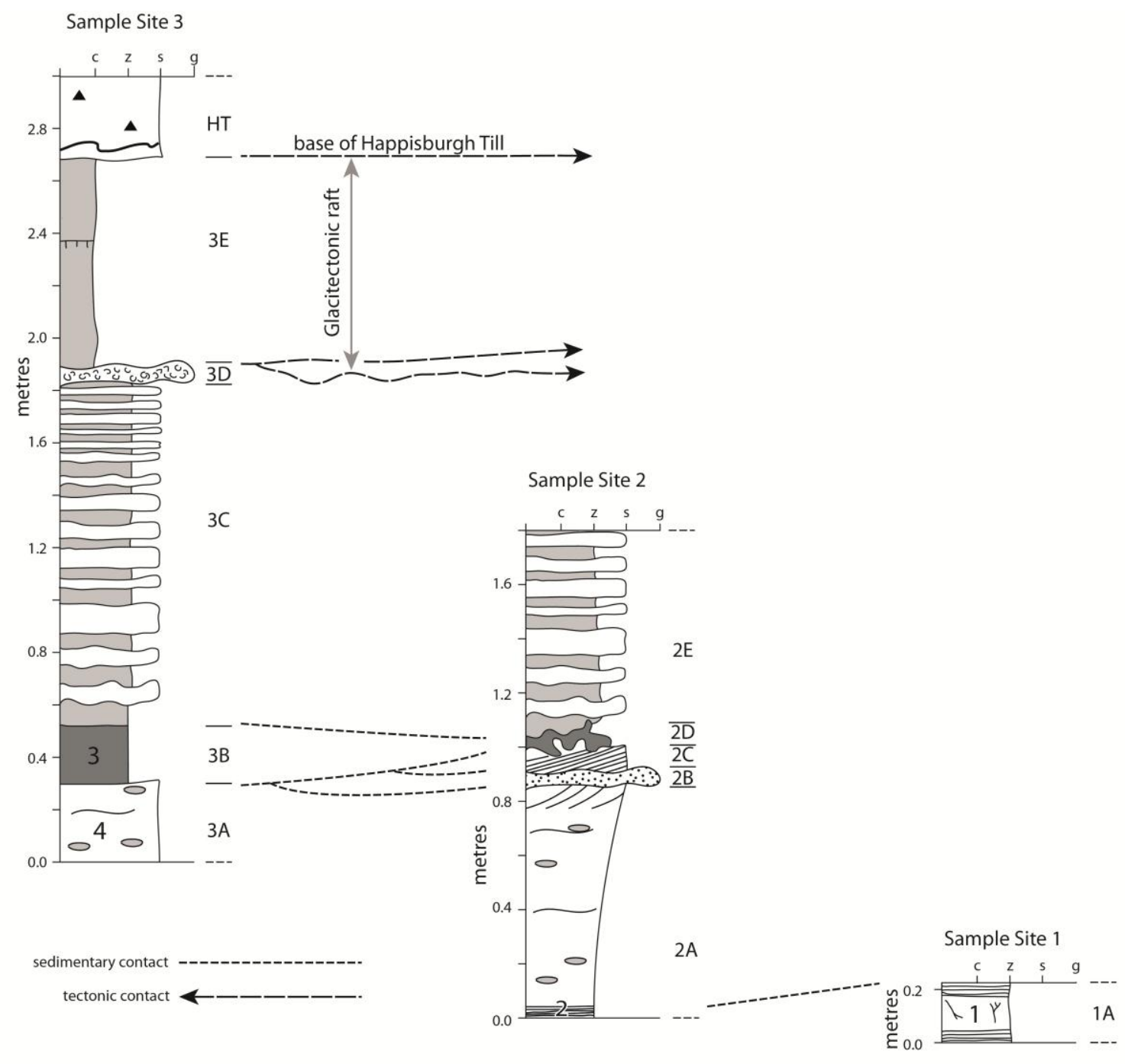

SOUTHEAST

NORTHWEST

Fig. 5 Logs of Samples Sites 1, 2 and 3 at Sidestrand showing the distribution and correlation of the main geological units (e.g. $1 A, 2 A-E, 3 A-E)$ and relative location of the samples (1-4). True vertical scale for individual logs is shown but their correlation is schematic.

Units $2 E$ and $3 C$ record a switch in the mode of sedimentation from fluviatile to shallow marine and coastal. The rhythmically-laminated sands and silts which form Unit $2 E$ and $U$ nit $3 C$ are interpreted as tidal rhythmites and reflect cyclic patterns of sedimentation during ebb (silt) and flood (sand) tides (Terwindt, 1971; Mazumder and Arima, 2005). At Sample Site 3, the vertical transition to silt-dominated rhythmites reveals a marked increase in sedimentation during the ebb tide. A distinctive feature of both Sample Sites 2 and 3 is the abundance of load-induced soft sediment deformation structures which imply rapid and / or high rates of sedimentation (Lowe, 1975; Owen, 1996). 
Shallow marine tidal rhythmites are truncated within Sample Site 3 by a thin lens of shell-rich diamict (Unit $3 D$ ) and in-turn by a relatively thick unit (Unit $3 E$ ) of organic silty clay that contains a palaeosol. Taken at face value, the presence of mollusc shells including Arctica islandica and Macoma obliqua suggest a switch to shallow marine sub-littoral sedimentation. Likewise, at face value, the sedimentology of Unit $3 E$ is indicative of low-energy suspension-settling within vegetated wetland terrestrial environment (e.g. an oxbow lake) with deposition punctuated by hiatuses and phases of soil development (Toonen et al., 2012). However, the truncating relationship of both units to Unit $3 C$, the flame-like margins of Unit $3 D$, the presence of attenuated sediment inclusions and detachment surfaces towards the base of Unit $3 E$ is not suggestive of a sedimentary mode of emplacement. Instead, it is suggested that these units are not in situ and have been remobilised by shearing and/or possible thrusting (cf. Hart \& Boulton, 1991; McCarroll \& Rijsdijk, 2003; Evans et al., 2006; Hart, 2007).

\section{Coleoptera and palaeobotany}

\subsection{Coleoptera \\ 5.1.1 Coleopteran assemblage}

All of the identifiable insect remains recovered from these samples were of Coleoptera. Their preservation was poor and fragmentary, making identification difficult in many cases. Altogether fifty-nine beetle taxa were recognised of which thirty-seven could be determined to species or species group (Table 1). Of the latter, ten species are no longer living in the British Isles. As well as these, many other fragments were too decomposed to identify, which, together with the fact that so many species in this assemblage are represented by single individuals, indicates that the actual beetle fauna at this time was undoubtedly considerably larger than the one recorded here.

Sample 1 (Sample Site 1 - Unit 1A) consisted of coarse compacted plant fragments in a matrix of fine silt and clay whilst the other samples were largely fine sand and abundant organic fragments with scattered plant and insect remains. Sample 2 (Sample Site 2 Unit 2A) yielded the richest fauna and the greatest number of specimens. Samples 3 (Unit 3B) and 4 (Unit 3A) from Sample Site 3 yielded very few specimens although the Helophorus glacialis (Sample 4) is also abundant in Sample 2 (Sample Site 2). The low abundance of beetle specimens in both these samples may be due to the abrasiveness and winnowing effects of sediment transport and deposition associated with Units $3 A$ and $3 B$.

\subsubsection{Palaeoenvironment}

Coleopteran assemblages from Samples Sites 1 and 2 are derived from correlative units (Units $1 A$ and $2 A$ ) and can therefore be used to provide a detailed insight into the local environment. Amongst the predatory water beetles, Hydroporus palustris lives in both stationary and running water. Potamonectes griseostriatus represents a species complex that lives in shallow temporary ponds or the margins of lakes especially where there is little aquatic vegetation. In contrast Ilybius lives in ponds where there is abundant vegetation. The hydraenids and hydrophilids have predatory larvae but adults that feed on decomposing vegetation. Hydrobius fuscipes and Enochrus live in wellvegetated ponds. The abundant Helophorus glacialis has rather specialist requirements since it lives on the edges of melting snow patches where the water is close to freezing (Hansen, 1987). The ground beetle Pelophila borealis lives in wet grassland areas preferring sandy or gravelly soils that have a mixture of muddy clay. It is especially abundant beside the lower reaches of larger rivers (Lindroth, 1992). The predator 
Bembidion fellmanni is a true alpine and tundra species, living predominantly on the banks of brooks and rivers and on lake margins. It is also found at the edges of snow patches. It prefers gravelly soils that are usually completely barren and bare of vegetation cover (Lindroth, 1992). Almost all the staphylinid species in this assemblage are predators on small soil arthropods and worms amongst damp plant detritus. Bembidion velox and Bembidion lapponicum live in thinly vegetated habitats beside rivers and lakes where the adults excavate burrows in firm, moist sand probably for breeding purposes. Phytophagous species that occupy moist habitats include Plateumaris sericea, Notaris bimaculatus and Notaris aethiops which feed on reedy vegetation such as Carex in marshy areas. Phyllodecta sp. feeds on the leaves of Salix bushes. Simplocaria metallica, Morychus sp, and Byrrhus arietinus feed exclusively on mosses. Helophorus obscurellus and Helophorus nubilus, in contrast to most members of this genus which are aquatic, live in damp sandy habitats where their larvae and adults are phytophagous. Aegialia sabuleti is found at the roots of grasses in damp sandy places. The click beetle Hypnoidus riparius lives in damp grassland where its larvae feed on roots. Otiorhynchus arcticus, Otiorhynchus dubius, Barynotus obscures/squamosus and Alophus triguttatus are heavy, flightless weevils that are polyphagous, feeding on a variety of herbaceous plants in damp sandy situations. Their larvae are subterranean feeding on roots. According to Böcher (1988) Otiorhynchus arcticus shows a clear tendency to prefer drier habitats than those chosen by Otiorhynchus dubius. Drier ground is indicated by Notiophilus aquaticus which, in spite of its name, does not require humid habitats, but lives on dry gravelly soils in open country where it preys upon mites, Collembola and other arthropods. In the mountains it is mainly found on heaths with grasses or dwarf shrubs (Lindroth, 1986). Pterostichus brevicornis is found in rather dry heaths or meadow-like habitats, often amongst grass and leaves, most often on the tundra. The relatively common weevil Apion is a member of an enormous genus many of which feed on various species leguminous plants. It is therefore interesting to note the equal abundance of Sitona, a weevil whose adults feed on similar plants; the larvae living underground where the early stages feed on the bacterial nodules. Some species have other specialist habitats not covered by the above categories. Thus Hippodamia arctica feeds on aphids chiefly on small Salix bushes. Species of Aphodius usually feed on dung though they can sometimes be found in heaps of decomposing vegetation. Thanatophilus dispar lives exclusively on carrion. Both occur here as single fragments suggesting that their preferred habitat was not common.

In summary the local environment consisted of a shallow pool surrounded by reed-like plants. There is no evidence from the beetle fauna for the local presence of trees and the landscape was likely open with sandy soil thinly vegetated with herbaceous plants.

\subsubsection{Palaeoclimate}

All the species in this beetle assemblage can only be found today in the northernmost parts of Europe; some of them exclusively in arctic regions. The most climatically significant species include the following;

(a) Bembidion lapponicum; a circumpolar species whose range extends from the mountains of western Fennoscandia across northern Siberia.

(b) Bembidion cf. fellmanni; a difficult identification because in eastern Asia there are a number of closely related species belonging to the subgenus Plataphodes which would be impossible to separate on fossil evidence alone. B. fellmanni is a boreo-alpine species, found extensively in the arctic regions of Europe and Asia but extending southwards into the mountains of Norway. In central Europe it is known only from the eastern part of the Transylvanian Alps. 
(c) Pterostichus cf. brevicornis; a difficult identification because this species belongs to the complex subgenus Cryobius which has many related species in eastern Asia and North America. P. brevicornis circumpolar species at all high northern altitudes whose closest occurrence today is on the extreme east of the Kola Peninsula.

(d) Ochthebius kaninensis; an extraordinarily rare species today known from five individuals from the Kanin Peninsula and a single individual from northern Finland. It has been found previously as a fossil in Devensian deposits (Hansen, 1987).

(e) Helophorus obscurellus; whose nearest locality today is on the north coast of the Kanin Peninsula in arctic Russia. The species is widespread on the cold steppes of central Asia from the Tibetan plateau to northern Siberia (Angus, 1992).

(f) Helophorus glacialis; a boreo-montane species that is widespread in the mountains and north of Fennoscandia and also at high altitudes in Spain, the Alps, the Appenine Mountains of Italy and the Carpathian Mountains.

(g) Olophrum boreale; a boreo-alpine species, ranging across northern Eurasia and in central Europe only known from the High Tauern mountains in Austria, where it is known as Olophrum florae Scheerp.

(h) Simplocaria metallica; a boreo-montane species ranging from Greenland and northern Fennoscandia to isolated localities in the mountains of central Europe. It is likely that there is some confusion of this species with other northern Simplocaria species such as remota and elongata and its distribution may be more widespread in the far north than has been hitherto recorded.

(i) Hippodamia arctica; a ladybird of the high northern parts of Fennoscandia and Russia with an isolated subspecies in the Caucasus Mountains.

With the exception of two species (Pelophila borealis and Notaris aethiops which still live in northern Britain today but are widespread across northern Eurasia east to Alaska), all of the above species are extinct at the present day in the British Isles though they all have been found previously here in deposits that date from various cold periods. Other species in this assemblage can tolerate extremely cold conditions though they are not strictly cold-adapted. They should thus be seen as facultative rather than obligate cryophiles.

Viewed as a whole this beetle assemblage indicates severely cold and rather continental climatic conditions though it lacks some of the exclusively Siberian and central Asiatic species that characterise the faunas from fully glacial conditions in Britain.

Using the Mutual Climatic Range (MCR) method it is possible to provide quantified estimates of the palaeotemperatures of the time based on Coleopteran assemblages (Atkinson et al., 1987). Only carnivorous or generally scavenging species are used in order to arrive at estimates that are independent of those derived from the macrophyte vegetation. Twelve species in this assemblage are also on the MCR database. They gave the following figures, where Tmax is the mean temperature of the warmest month (July) and Tmin is the mean temperature of the coldest months (January and February): Tmax lay somewhere between $10^{\circ} \mathrm{C}$ and $13^{\circ} \mathrm{C}$, and Tmin lay somewhere between $-17^{\circ} \mathrm{C}$ and $-10^{\circ} \mathrm{C}$.

Sensitivity tests of the MCR method have been carried out using present day beetle faunas and comparing the MCR estimated temperatures obtained from them with those actually measured at nearby meteorological stations (Coope et al., 1998). These tests indicate that, during cold periods, the MCR estimates are slightly too high and that 
the actual palaeotemperatures of the time were probably towards the lower end of the ranges given above.

Although it is not possible to quantify precipitation levels on the basis of this Coleopteran assemblage the fauna suggests that adequate moisture must have been available during the summer months to provide aquatic or marshy habitats for several of the beetle species. However, in the cold conditions outlined above, evaporation rates would be low and the ground moisture necessary to sustain the damp habitats need not necessarily mean that there was much summer precipitation at this time.

\subsection{Palaeobotany}

\subsubsection{Sample Site 1}

Unfortunately, although some pollen was present (from Poaceae (grass), Pinus (Pine) and Polypodium (fern spores)), it is not possible to draw any conclusions regarding the regional vegetation based on the pollen due to their low concentration in the samples. However, the local vegetation can be inferred to an extent from the macrofossils. Although Sample 1 was rich in macroflora material, potentially identifiable specimens were present in scant quantities and in deteriorated condition. These factors prevented identification of some of the specimens and only permitted tentative identification of others. The taxa identified and their associated environments are summarised in Table 2. These indicate local environments that contain open grassland and/or bare ground habitats (e.g. Plantago sp.). Locally, there also appears to have been damp ground colonised by mare's tail (Hippuris vulgaris) and club-rushes (Scirpus sp.) as well as a pool or slow flowing river colonised by water lily (Nymphaea sp.), pondweed (Potamogeton) and quillwort (Isoetes). Whilst the small sample size makes it difficult to comment with confidence, it is interesting to note that all the taxa identified have also been associated with cold climates, with Selaginella particularly cited in association with cold stage floral assemblages ( $c f$. Godwin, 1975; West, 2000).

\subsubsection{Sample Site 2}

The pollen concentration of Sample 2 was low, although the preservation was fairly good allowing identification of some pollen taxa (Table 3). The pollen assemblage comprised of a mix of arboreal and herbaceous taxa dominated by coniferous elements. Whilst the Pinus component is likely to have been derived from a regional source, the frequency of Picea suggests a local source. The significance of Quercus and Corylus are difficult to establish and may be due to re-working. The limited herbaceous elements suggest there may be some open areas in the regional environment, with the Cyperaceae, Sphagnum and Pediastrum suggesting possible damp or pool environments. Identifiable macroflora remains were not present in this sample, and there are no results for Sample Site 3.

\section{Discussion}

\subsection{Genetic and stratigraphic model}

Sediments examined within these excavations at Sidestrand can be correlated with the wider established preglacial early Middle Pleistocene stratigraphy in northern East Anglia (West, 1980; Preece \& Parfitt, 2000; Rose et al., 2001, 2002; Pawley et al., 
2004; Lee et al., 2006; Preece et al., 2009). During this time-interval, the East Anglia region occupied a low-relief coastal plain drained by several large river systems that extended eastwards from central and eastern England into the North Sea Basin (Rose et al., 2001, 2002; Rose, 2009). Neotectonic uplift and subsidence, coupled with cycles of climatic and eustatic change acted to drive marked temporal and spatial changes in regional palaeogeography and switches between shallow marine, coastal, and terrestrial modes of sedimentation and soil development (Allen \& Keen, 2000; Lee et al., 2006; Rose, 2009).

Based on correlation with previous studies undertaken at Sidestrand (cf. West, 1980; Briant et al., 1999; Lee, 2009; Preece et al., 2009), the observed sections in this study occur above the Sidestrand Hall Member of the CF-bF (Preece et al., 2009) also known as the Sidestrand Unio Bed (Cromer Forest-bed Formation) but beneath the Happisburgh Till Member that caps the sequence (Fig.6). Key marker units that aid this correlation are the thick sequence of tidal rhythmites (Units $2 E$ and $3 C$; Unit $\mathrm{J}$ of Lee, 2009) that can be traced between Overstrand and Trimingham (West, 1980; Briant et al., 1999; Lee, 2009), and the hummocky cross-bedded gravels (Unit H of Lee, 2009) that crop-out on the foreshore beneath Sample Site 1.

The fluviatile deposits that occur at the base of the observed succession (Units $1 A$, $2 A$ and $3 A$ ) are inferred to occupy a previously unrecognised shallow fluvial channel that is incised into Unit I of Lee (2009). Together with Units $2 B-D$ and Unit $3 C$ they record a switch from shallow marine to fluvial sedimentation under an arctic (boreo-alpine) climate and collectively form part of the Cromer Forest-bed Formation (West, 1980; Allen \& Keen, 2000; Preece \& Parfitt, 2000; Rose et al., 2001; Preece et al., 2009). The Cromer Forest-bed Formation is widely considered to relate to a 'northern river' (sometimes referred to as the Ancaster River) that drained eastwards from central England into the North Sea via the area of northeast Norfolk and the modern offshore area immediately to the north of Norfolk (Green \& McGregor, 1990; Briant et al., 1999; Rose et al., 2001; Lee, 2009).

Overlying these fluvial deposits between Sidestrand and Trimingham are shallow marine and coastal deposits of the Wroxham Crag Formation (Briant et al., 1999; Lee, 2009). The Wroxham Crag Formation represents the youngest stratigraphic sub-division of the Crag Group in East Anglia and can be assigned broadly to the late Early and early Middle Pleistocene (Rose, 2009) and both overlies and underlies the Sidestrand Unio Bed in the vicinity of Sidestrand and Overstrand (Lee, 2009).

The uppermost units of the observed succession (Units $3 D$ and $3 E$ ) occur immediately beneath the Happisburgh Till Member which represents the first known glacial incursion into lowland eastern England during the Pleistocene (Lee et al., 2004b; Rose, 2009). Based upon structural evidence it is suggested that these units are not in situ but have been remobilised tectonically. This assertion is further supported by the occurrence of the marine mollusc Macoma obliqua (Unit $3 D$ ) within a much younger stratigraphic position than previously found. Meijer (1993), for instance, has argued that Macoma obliqua does not occur within Early Pleistocene sediments younger than the 'Weybourne Crag' which are broadly comparable to the late Tiglian of the Netherlands (Harrison \& Parfitt, 2009). Critically, the 'Weybourne Crag' (now known as the Sidestrand Member of the Norwich Crag Formation) occurs locally at Overstrand resting unconformably upon Chalk bedrock (Reid, 1882, 1890; West, 1890) and this is the likely source for Unit $3 D$. Both Units $3 D$ and $3 E$ are interpreted to have been transported and stacked up-sequence by glacitectonism associated with the accretion of the Happisburgh Till Member. This 'stratigraphic inversion' - namely the emplacement of older sediment units unconformably upon younger strata, is a common feature of thrust tectonics (Twiss, 1992; van Gool et al., 1999) in glacigenic terranes (van der Wateren, 1985, 1995; 
Lee et al., 2013). Unit $3 E$ appears to have been remobilised largely en bloc (i.e. as a tectonic raft) with movement accommodated along discrete detachments (shears) within the basal $0.1 \mathrm{~m}$ of the unit. These discrete shears appear to form part of a more laterallyextensive and gently-undulating lower thrust surface that by inference extends northwards (basal contact of Unit $3 E$ ). By contrast, Unit $3 D$ has been deformed plastically with wispy flame-like margins and sediment inclusions indicating elevated porewater pressures during deformation. Preservation of the mollusc shells is likely to have been aided by increased (and confined) porewater pressures and associated sediment dilation which would have acted to reduce inter-granular contacts (Hicock \& Dreimanis, 1992; Piotrowski et al., 2004). The presence of a confined and partiallyliquified clay beneath Unit $3 E$ is likely to have lubricated basal-sliding of the raft. Lowangle thrust detachments extending to depths of approximately $3 \mathrm{~m}$ beneath the base of the Happisburgh Till Member have previously been recognised at Overstrand and Sidestrand and relate to the application of subglacial shear stresses to the preglacial sediment pile from the north (Lee, 2009). However, the inclusion of 'Weybourne Crag' within the deformed assemblage which occurs at least $7 \mathrm{~m}$ beneath the Happisburgh Till Member suggests that zone of thrusting thickens northwards 'up ice'.

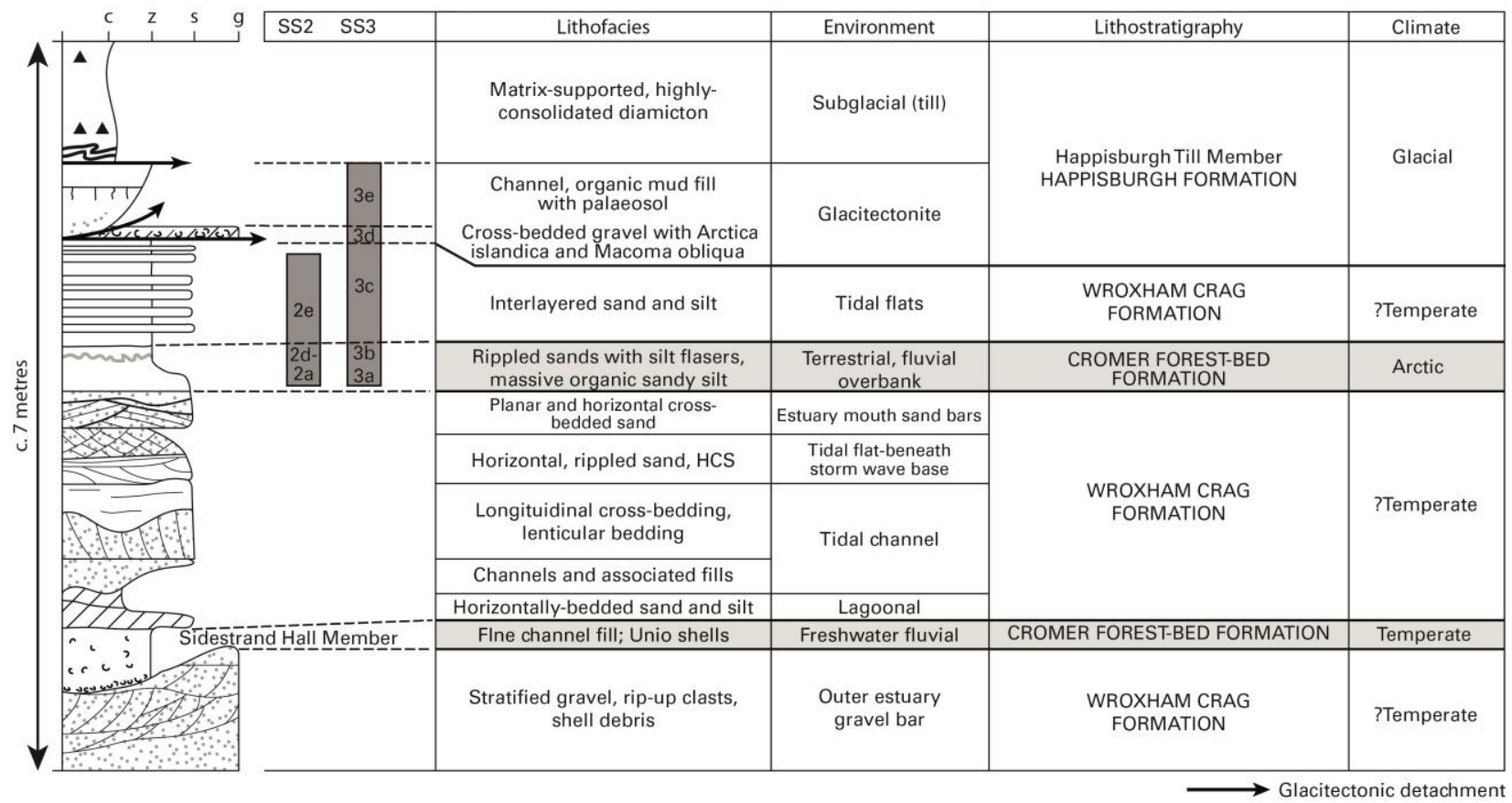

Fig. 6. The stratigraphy of the cliff and beach sections at Sidestrand (modified from Lee, 2009).

\subsection{Chronology}

Early Middle Pleistocene sediments at Sidestrand provide important stratigraphic markers that are central to reconciling the age of the arctic freshwater units and more widely the timing of the onset of lowland glaciation in eastern England (represented by the Happisburgh Till Member). Opinions relating to the latter are divided between an Anglian (Marine Isotope Stage (MIS) 12) age (Banham et al., 2001; Preece, 2001; Preece et al., 2009; Westaway, 2010; Preece \& Parfitt, 2012) or an older 
glaciation possibly equivalent to MIS 16 (Hamblin et al., 2005; Lee et al., 2004b; Rose, 2009).

The Sidestrand Unio Bed occurs stratigraphically beneath the arctic freshwater units examined within the excavations and is central to the debate. The deposit occurs as two discrete horizons. Firstly, a lower unit of shelly sand and gravel approximately 0.25 $m$ thick (Reid, 1882; Preece et al., 2009); and secondly, a shelly upper unit of blue clay approximately 1-2 m thick (Reid, 1882; Preece et al., 2009). Delicate remains of plants and insects and some articulated bones have been preserved in the upper bed, as well as unionids and other bivalves with united valves that still retain the periostracum. The Coleopteran fauna of the upper bed indicate a climate several degrees warmer than the present day during a preglacial temperate stage post-dating the Cromerian sensu stricto (Preece et al., 2009). Both the Upper and the Lower Unio Beds at Sidestrand were dated to a younger 'Cromerian Complex' age of either MIS 15 or 13 by biostratigraphy and aminostratigraphy (Preece et al. 2009), although this has been subsequently refined to MIS 13 (Westaway, 2010; Penkman et al, 2013). This is consistent with the presence of the water vole Arvicola within the Unio Bed, also suggesting an age late in the 'Cromerian Complex' (Preece \& Parfitt, 2012). If this chronology is correct, it would place the arctic freshwater deposits identified within this study as being deposited during the succeeding cold stage - namely the Anglian (MIS 12). However, other conclusions drawn from this study and earlier work raise significant questions relating to the validity of this assertion (Lee, 2009). Specifically, the Sidestrand Unio Bed and the Happisburgh Till Member are separated by a sediment package that provides relative evidence of at least two marine transgressions (Wroxham Crag Formation) and an intervening marine regression associated with the deposition of the arctic freshwater units. The climatic significance of these marine deposits is not known at Sidestrand but tidal rhythmites (Unit $2 E \& 3 C$ ) that occur in a similar stratigraphic position at nearby Trimingham are of temperate affinity (Unit D of Briant et al., 1999). Further work examining the palaeoclimatic significance of the shallow marine deposits at Sidestrand is therefore required to build a more complete robust geological and stratigraphical model for the site.

\subsection{Palaeoclimatic significance of the arctic beds}

Comparatively little evidence currently exists that quantifies Early and early Middle Pleistocene preglacial cold climates in the UK. In addition to Sidestrand described here, only two other sites of broadly comparable age have yielded cold climate Coleopteran faunas. An early cool-climate Coleopteran fauna of Early Pleistocene (PrePastonian) age was described from Beeston in North Norfolk (West 1980 page 35, level i,) by Coope (2000) but this indicated only moderately cool conditions equivalent to those in northern Britain at the present day. The 'Arctic Fresh-water Bed' at Ostend in North Norfolk has been assigned to the Bacton Member of the Cromer Forest-bed Formation and formed during the early Anglian, correlated with MIS 12 (Parfitt et al., 2010b). The Coleoptera from a small exposure of this bed included three beetle species (Pterostichus brevicornis, P. middendorffi and Helophorus obscurellus) that today have their closest occurrences on either the Kanin or Kola peninsulas in arctic Russia (two of these occur at Sidestrand: P. brevicornis, and H. obscurellus). A Mutual Climatic Range (MCR) reconstruction on the limited beetle fauna at Ostend suggests that the mean temperatures of the warmest and coldest months were between $9^{\circ} \mathrm{C}$ and $11^{\circ} \mathrm{C}$ and between $-36^{\circ} \mathrm{C}$ and $-10^{\circ} \mathrm{C}$, respectively. The fauna is distinctly high boreal/arctic in character, indicating a small, possibly ephemeral, pool in a generally open landscape supporting some dwarf shrubs and conifers. By comparison, the MCR reconstruction for 
the much richer assemblage from Sidestrand indicates that the mean temperatures of the warmest and coldest months were between $10^{\circ} \mathrm{C}$ and $13^{\circ} \mathrm{C}$ and between $-17^{\circ} \mathrm{C}$ and $-10^{\circ} \mathrm{C}$. Both sites therefore indicate quite cold environments. The MCR for the Sidestrand fauna is not necessarily indicative of a slightly cooler climate as the MCR values from the two sites overlap and could represent the same climatic conditions with the larger assemblage from Sidestrand allowing temperatures to be constrained more tightly (Ostend's assemblage is significantly smaller and therefore prone to larger statistical errors). Both sites are demonstrably preglacial, with the Sidestrand material providing a more robust assemblage in terms of the total numbers of taxa (59, compared to Ostend's 10) and in their diversity.

Evidence for such pronounced early Middle Pleistocene preglacial cold climates is in accordance with the widespread evidence of periglacial phenomena including icewedge casts, frost cracks and cryoturbation (Rose \& Allen, 1977; West, 1980; Kemp et al., 1993; Murton et al., 1995; Whiteman, 2002; Candy et al., 2010). Several localities in East Anglia, including Corton (Gardner \& West, 1975; Lee et al., 2003), Trimingham (Briant et al., 1999) and West Runton (West, 1980; Rose et al., 2008), also show multiple horizons of ice-wedge casts separated by intervening temperate sediments indicating several cold climate periglacial phases occurred during the early Middle Pleistocene (Lee et al., 2003; Candy et al., 2010). This disagrees with several regional-scale palaeoclimate proxies (i.e. the oxygen isotope record) which suggest less intense cold-stage climates occurred during the early Middle Pleistocene.

\section{Conclusions}

- Cold stage beetle assemblages have been recovered from early Middle Pleistocene fluvial sediments at Sidestrand, north Norfolk. This fauna is of particular interest because of its climatic significance (showing extremely cold boreo-alpine arctic winter conditions) and its extent (comprising 59 beetle taxa).

- These assemblages provide palaeontological evidence which in tandem with evidence for periglacial processes from other sites in the region, demonstrate that cold stage climates during this time interval were in part extreme. This is in strong discrepancy with other relative climate proxies (e.g. the global record of ice volume) which indicate less intense cold stage climates during the early Middle Pleistocene as opposed to the late Middle and Late Pleistocene.

- The arctic assemblage is overlain and underlain by shallow marine coastal deposits (Wroxham Crag Formation) which are in turn constrained by two important stratigraphic markers. Firstly, the temperate stage Sidestrand Unio Bed (base) and the Happisburgh Till Member (top) which forms the basal glacigenic unit in the region. The precise age of this arctic assemblage remains equivocal.

\section{Acknowledgements}

For stimulating discussion and encouragement we would like to thank: Simon Parfitt and Chris Stringer (the Natural History Museum, London); Richard Preece (Cambridge University Museum of Zoology); and Peter Hoare (Norwich Castle Museum). Silvia Bello (Natural History Museum) helped with the illustrations; Simon Parfitt and Peter Hoare provided the sediment analysis; Leanne Hughes and two anonymous referees produced useful comments that have helped improve the 
manuscript. This is a contribution to the Ancient Human Occupation of Britain and its European Context (AHOB 3) project funded by the Leverhulme Trust. JRL publishes with the permission of the Executive Director of the British Geological Survey (NERC).

\section{References}

Allen, P., Keen, D.H., 2000. Uppermost Norwich Crag and Lower Part of the Cromer Forest-bed Formation, In: Lewis, S.G., Whiteman, C.A., Preece, R.C. (Eds.), The Quaternary of Norfolk and Suffolk: Field Guide. Quaternary Research Association, London, pp. 29-34.

Angus R.B., 1992. Insecta Coleoptera Hydrophilidae Helophorinae. Süsswasserfauna von Mitteleuropa, 20/10-2, 1-144. Gustav Fischer, Stuttgart.

Ashton, N., Lewis, S.G., 2012. The environmental contexts of early human occupation of northwest Europe: The British Lower Palaeolithic record. Quaternary International 271, 50-64.

Atkinson, T. C., Briffa, K. R., Coope, G. R., 1987. Seasonal temperatures in Britain during the past 22,000 years, reconstructed using beetle remains. Nature London, 325, 587592.

Banham, P.H., Gibbard, P.L., Lunkka, J.P., Parfitt, S.A., Preece, R.C., Turner, C., 2001. A critical assessment of 'a new glacial stratigraphy for eastern England. Quaternary Newsletter 93, 5-14.

Bhattacharya, A., 1997. On the origin of non-tidal flaser bedding in point bar deposits of the river Ajay, Bihar and West Bengal, NE India. Sedimentology 44, 973-975.

Böcher J., 1988. The Coleoptera of Greenland, Meddelelser om Grønland, Bioscience 26, 1-100.

Böse, M., Lüthgens, C., Lee, J.R., Rose, J., 2012. Quaternary glaciations of northern Europe. Quaternary Science Reviews 44, 1-25.

Briant, R.M., Rose, J., Branch, N.P., Lee, J.A., 1999. Preglacial Quaternary sediments from Trimingham, North Norfolk, England. Bulletin of the Geological Society of Norfolk 49, $15-47$.

Burke, H., Phillips, E., Lee, J.R., Wilkinson, I.P., 2009. Imbricate thrust stack model for the formation of glaciotectonic rafts: an example from the Middle Pleistocene of north Norfolk, UK. Boreas 38, 620-637.

Candy, I., Rose, J., Lee, J.R., 2006. A seasonally 'dry' interglacial climate in Eastern England during the early Middle Pleistocene: palaeopedological and stable isotope evidence from Pakefield, UK. Boreas 35, 255-265.

Candy, I., Coope, G.R., Lee, J.R., Parfitt, S.A., Preece, R.C., Rose, J., Schreve, D.C., 2010. Pronounced warmth during early Middle Pleistocene interglacials: Investigating the 
Mid-Brunhes Event in the British terrestrial sequence. Earth-Science Reviews 103, 183196.

Coope, G. R., 1986. Coleoptera analysis. In B. E. Berglund (ed.) Handbook of Holocene Palaeoecology and Palaeohydrology, 703-713. J. Wiley \& Sons, Chichester.

Coope, G.R., 2000. Coleoptera from Beeston and West Runton, Norfolk. In: Lewis, S.G. Whiteman, C.A., Preece, R.C. (Eds.), The Quaternary of Norfolk \& Suffolk. Quaternary Research Association, London, pp. 73-76.

Coope, G.R. Lemdahl, G, Lowe, J.J., Walkling, A., 1998. Temperature gradients in northern Europe during the last glacial-interglacial transition (14-9 ${ }^{14} \mathrm{C} \mathrm{kyr} \mathrm{BP}$.) interpreted from coleopteran assemblages, Journal of Quaternary Science, 13 no 5, 419433 .

Evans, D.J.A., Phillips, E.R., Hiemstra, J.F., Auton, C.A., 2006. Subglacial till: Formation, sedimentary characteristics and classification. Earth-Science Reviews 78, $115-176$.

Fielding, C., 1986. Fluvial channel and overbank deposits from the Westphalian of the Durham coalfield, NE England. Sedimentology 33, 119-140.

Fish, P.R., Carr, S.J., Rose, J., Hamblin, R.J.O., Eissmann, L., 1998. A periglacial composite-wedge cast from the Trimingham area, north Norfolk, England. Bulletin of the Geological Society of Norfolk 46, 11-16.

Flesche Kleiven, H., Jansen, E., Fronval, T., Smith, T.M., 2002. Intensification of Northern Hemisphere glaciations in the circum Atlantic region (3.5-2.4 Ma) - ice-rafted detritus evidence. Palaeogeography, Palaeoclimatology, Palaeoecology 184, 213-223.

Funnell, B.M., West, R.G., 1962. The early Pleistocene of Easton Bavents, Suffolk. Quarterly Journal of the Geological Society of London 118, 125-141.

Gardner, K., West, R.G., 1975. Fossil ice-wedge polygons at Corton, Suffolk. Bulletin of the Geological Society of Norfolk 23, 47-53.

Godwin, H., 1975. History of the British Flora. Cambridge University Press, UK, $2^{\text {nd }}$ Edition, $541 \mathrm{p}$.

Green, C.P., McGregor, D.F.M., 1990. Pleistocene gravels of the north Norfolk coast. Proceedings of the Geologists' Association 101, 197-202.

Hamblin, R.J.O., Moorlock, B.S.P., Rose, J., Lee, J.R., Riding, J.B., Booth, S.J., Pawley, S.M., 2005. Revised Pre-Devensian glacial stratigraphy in Norfolk, England, based on mapping and till provenance. Geologie en Mijnbouw 84, 77-85.

Hansen, M., 1987. The Hydrophiloidea (Coleoptera) of Fennoscandia and Denmark. Fauna Entomological Scandinavica, 18, 1-254.

Harrison, D.L., Parfitt, S.A., 2009. Fossil remains of shrews (Soricomorpha: Soricidae) and desmans (Talpidae: Desmaninae) from Norfolk, England, with biostratigraphic 
implications for the Plio-Pleistocene boundary in East Anglia. Acta Zoologica Cravoviensia 52A, 61-79.

Hart, J.K., 1990. Proglacial glaciotectonic deformation and the origin of the Cromer Ridge push moraine, north Norfolk, England. Boreas 19, 165-180.

Hart, J.K., 1992. Sedimentary environments associated with glacial Lake Trimingham, Norfolk, UK. Boreas 21, 119-136.

Hart, J.K., 2007. An investigation of subglacial shear zone processes from Weybourne, Norfolk, UK. Quaternary Science Reviews 26, 2354-2374.

Hart, J.K., Boulton, G.S., 1991. The interrelation of glaciotectonic and glaciodepositional processes within the glacial environment. Quaternary Science Reviews 10, 335-350.

Hicock, S.R., Dreimanis, A., 1992. Deformation till in the Great Lakes region: implications for rapid flow along the south-central margin of the Laurentide Ice Sheet. Canadian Journal of Earth Sciences 29, 1565-1579.

Imbrie, J., Hays, J.D., Martinson, D.G., McIntyre, A., Mix, A.C., Morley, J.J., Pisias, N.G., Prell, W.L., Shackleton, N.J., 1984. The orbital theory of Pleistocene climate: Support from a revised chronology of the marine delta18 O record, Milankovitch and climate: Understanding the response to astronomical forcing, p. 269.

Kemp, R.A., Whiteman, C.A., Rose, J., 1993. Paleoenvironmental and Stratigraphic Significance of the Valley Farm and Barham Soils in Eastern England. Quaternary Science Reviews 12, 833-848.

Knies, J., Matthiessen, J., Vogt, C., Laberg, J.S., Hjelstuen, B.O., Smelror, M., Larsen, E., Andreassen, K., Eidvin, T., Vorren, T.O., 2009. The Plio-Pleistocene glaciation of the Barents Sea-Svalbard region: a new model based on revised chronostratigraphy. Quaternary Science Reviews 28, 812-829.

Larkin, N.R., Lee, J.R., Connell, E.R., 2011. Possible ice-rafted erratics in late Early to early Middle Pleistocene shallow marine and coastal deposits in northeast Norfolk, UK. Proceedings of the Geologists' Association 122, 445-454.

Lee, J.R., 2001. Genesis and palaeogeographical significance of the Corton Diamicton (basal member of the North Sea Drift Formation), East Anglia, U.K. Proceedings of the Geologists' Association 112, 29-43.

Lee, J.R., 2009. Patterns of preglacial sedimentation and glaciotectonic deformation within early Middle Pleistocene sediments at Sidestrand, north Norfolk, UK. Proceedings of the Geologists' Association 120, 34-48.

Lee, J.R., Brown, E.J., Rose, J., Moorlock, B.S.P., Hamblin, R.J.O., 2003. A Reply to 'Implications of a Middle Pleistocene Ice-Wedge Cast at Trimingham, Norfolk, Eastern England'. Permafrost and Periglacial Processes 14, 75-78.

Lee, J.R., Booth, S.J., Hamblin, R.J.O., Jarrow, A.M., Kessler, H., Moorlock, B.S.P., Morigi, A.N., Palmer, A.P., Riding, J.B., Rose, J., 2004a. A new stratigraphy for the 
glacial deposits around Lowestoft, Great Yarmouth, North Walsham, and Cromer, East Anglia, UK. Bulletin of the Geological Society of Norfolk 53, 3-60.

Lee, J.R., Rose, J., Hamblin, R.J.O., Moorlock, B.S.P., 2004b. Dating the earliest lowland glaciation of eastern England : a pre-MIS 12 early Middle Pleistocene Happisburgh Glaciation. Quaternary Science Reviews 23, 1551-1566.

Lee, J.R., Rose, J., Candy, I., Barendregt, R.W., 2006. Sea-level changes, river activity, soil development and glaciation around the western margins of the southern North Sea Basin during the Early and early Middle Pleistocene: evidence from Pakefield, Suffolk, UK. Journal of Quaternary Science 21, 155-179.

Lee, J.R., Rose, J., Hamblin, R.J.O., Moorlock, B.S.P., Riding, J.B., Phillips, E., Barendregt, R.W., Candy, I., 2011. The glacial history of the British Isles during the Early and Middle Pleistocene : implications for the long-term development of the British Ice Sheet, In: Ehlers, J., Gibbard, P.L., Hughes, P.D. (Eds.), Quaternary glaciations : extent and chronology. Elsevier, pp. 59-74.

Lee, J.R., Busschers, F.S., Sejrup, H.P., 2012. Pre-Weichselian Quaternary glaciations of the British Isles, The Netherlands, Norway and adjacent marine areas south of $68^{\circ} \mathrm{N}$ : implications for long-term ice sheet development in northern Europe. Quaternary Science Reviews 44, 213-228.

Lee, J.R., Phillips, E., Booth S.J., Rose J., Jordan H.M., Pawley S.M., Warren M., Lawley R.S., 2013. A polyphase glacitectonic model for ice-marginal retreat and terminal moraine development: the Middle Pleistocene British Ice Sheet, northern Norfolk, UK. Proceedings of the Geologists' Association 124, 753-777.

Lindroth, C.H., 1986. The Carabidae (Coleoptera) of Fennoscandia and Denmark. Fauna Entomologica Scandinavica, 15, 1-497.

Lindroth, C.H., 1992. Ground beetles (Carabidae) of Fennoscandia: a zoogeographical study. (English Translation of 1945 German text) pp 1-814 Intercept, Andover.

Lisiecki, L.E., Raymo, M.E., 2007. Plio-Pleistocene climate evolution: trends and transitions in glacial cycle dynamics. Quaternary Science Reviews 26, 56-69.

Lowe, D.R., 1975. Water escape structures in coarse-grained sediments. Sedimentology 22, 157-204.

Lucht W.H. 1987. Die Käfer Mitteleuropas: Katalog, pp 1-342, Goecke \& Evers, Krefeld.

Lunkka, J.P., 1994. Sedimentation and lithostratigraphy of the North Sea Drift and Lowestoft Till Formations in the coastal cliffs of northeast Norfolk. Journal of Quaternary Science 9, 209-233.

Martin, A., 2000. Flaser and wavy bedding in ephemeral streams: a modern and an ancient example. Sedimentary Geology 136, 1-5.

Mazumder, R., Arima, M., 2005. Tidal rhythmites and their implications. Earth-Science Reviews 69, 79-95. 
McCarroll, D., Rijsdijk, K.F., 2003. Deformation styles as a key for interpreting glacial depositional environments. Journal of Quaternary Science 18, 473-489.

Meijer, T., 1993. Stratigraphical notes on Macoma (Bivalvia) in the southern part of the North Sea Basin and some remarks on the arrival of Pacific species. Scripta Geologica Special Issue 2, 297-312.

Miall, A.D., 1996. The geology of fluvial deposits. Springer Berlin.

Moore, P.D., Webb, J.A., Collinson, M.E., 1991. Pollen analysis. Blackwell Scientific. Oxford. GB. 216 pp.

Mudelsee, M., Raymo, M.E., 2005. Slow dynamics of the Northern Hemisphere glaciation. Paleoceanography 20, PA4022.

Murton, J.B., Whiteman, C.A., Allen, P., 1995. Involutions in the Middle Pleistocene (Anglian) Barham Soil, Eastern England - a Comparison With Thermokarst Involutions From Arctic Canada. Boreas 24, 269-280.

Norton, P.E.P., 1967. Marine molluscan assemblages in the Early Pleistocene of Sidestrand, Bramerton and the Royal Society Borehole at Ludham, Norfolk. Philosophical Transactions of the Royal Society of London B25, 161-200.

Owen, G., 1996. Experimental soft-sediment deformation: structures formed by the liquefaction of unconsolidated sands and some ancient examples. Sedimentology 43, 279-293.

Pawley, S.M., Rose, J., Lee, J.R., Hamblin, R.J.O., Moorlock, B.S.P., 2004. Middle Pleistocene stratigraphy of Weybourne, north-east Norfolk, England. Proceedings of the Geologists' Association 115, 22-42.

Parfitt, S.A., Ashton, N.M., Lewis, S.G., Abel, R.L., Coope, G.R., Field, M.H., Gale, R., Hoare, P.G., Larkin, N.R., Lewis, M.D., Karloukovski, V., Maher, B.A., Peglar, S.M., Preece, R.C., Whittaker, J.E., Stringer, C.B. 2010a. Early Pleistocene human occupation at the edge of the boreal zone in northwest Europe. Nature, Vol 466, 8.

Parfitt, S.A., Coope, G.R., Field, M.H., Peglar, S.M., Preece, R.C., Whittaker, J.E. 2010b. Middle Pleistocene biota of the early Anglian 'Arctic Fresh-water Bed' at Ostend, Norfolk, UK. Proceedings of the Geologists’ Association 121 (2010) 55-65

Penkman, K.E.H., Preece R.C., Bridgland, D. R., Keen, D.H., Meijer, T., Parfitt, S.A., White, T.S., Collins, M. J., 2013. An aminostratigraphy for the British Quaternary based on Bithynia opercula. Quaternary Science Reviews 61, 111-134.

Piotrowski, J.A., Larsen, N.K., Junge, F.W., 2004. Reflections on soft subglacial beds as a mosaic of deforming and stable spots. Quaternary Science Reviews 23, 993-1000.

Preece, R.C., 2001. Molluscan evidence for differentiation of interglacials within the 'Cromerian Complex'. Quaternary Science Reviews 20, 1643-1656. 
Preece, R.C., Parfitt, S.A., 200o. The Cromer Forest-bed Formation: new thoughts on an old problem, In: Lewis, S.G., Whiteman, C.A., Preece, R.C. (Eds.), The Quaternary of

Norfolk and Suffolk: Field Guide. Quaternary Research Association, London, pp. 1-28.

Preece R.C, Parfitt, S.A., 2012. The Early and early Middle Pleistocene context of human occupation and lowland glaciation in Britain and northern Europe. Quaternary International 271, 6-28.

Preece, R.C., Parfitt, S.A.,Coope, G.R., Penkman, K.E.H., Ponel, P., Whittaker J.E., 2009. Biostratigraphic and aminostratigraphical constraints on the age of the Middle Pleistocene of north Norfolk, UK. Journal of Quaternary Science, 24, 557-580.

Reid, C., 1882. The Geology of the Country Around Cromer (Explanation of sheet 68 E). Memoir of the Geological Survey, UK.

Reid, C., 1890. The Pliocene Deposits of Britain. Memoir of the Geological Survey, UK.

Rose, J., 2009. Early and Middle Pleistocene landscapes of eastern England. Proceedings of the Geologists' Association 120, 3-33.

Rose, J., Allen, P., 1977. Middle Pleistocene stratigraphy in southeast Suffolk. Journal of the Geological Society of London 133, 83-102.

Rose, J., Moorlock, B.S.P., Hamblin, R.J.O., 2001. Pre-Anglian fluvial and coastal deposits in Eastern England: lithostratigraphy and palaeoenvironments. Quaternary International 79, 5-22.

Rose, J., Candy, I., Moorlock, B.S.P., Wilkinson, I.H., Lee, J.A., Hamblin, R.J.O., Lee, J.R., Riding, J.B., Morigi, A.N., 2002. Early and early Middle Pleistocene river, coastal and neotectonic processes, southeast Norfolk, England. Proceedings- Geologists Association 113, 47-68.

Rose, J., Juby, C., Bullen, M., Davies, S., Branch, N., Gammage, Z., Candy, I., Palmer, A., 2008. The stratigraphy, sedimentology, palaeoenvironments and duration of the early Middle Pleistocene sediments at West Runton, north Norfolk. In: Candy, I., Lee, J.R., Harrison, A.M. (Eds.). The Quaternary of northern East Anglia, Field Guide. Quaternary Research Association, London, 157-181.

Terwindt, J.H.R., 1971. Litho-facies of inshore estuarine and tidal inlet deposits. Geologie en Mijnbouw 50, 515-526.

Thierens, M., Pirlet, H., Colin, C., Latruwe, K., Vanhaecke, F., Lee, J.R., Stuut, J.B., Titschack, J., Huvenne, V.A.I., Dorschel, B., Wheeler, A.J., Henriet, J.P., 2012. Icerafting from the British-Irish ice sheet since the earliest Pleistocene (2.6 million years ago): implications for long-term mid-latitudinal ice-sheet growth in the North Atlantic region. Quaternary Science Reviews 44, 229-240.

Toonen, W.H.J., Kleinhans, M.G., Cohen, K.M., 2012. Sedimentary architecture of abandoned channel fills. Earth Surface Processes and Landforms 37, 459-472.

Twiss, R.J., Moores, E.M., 1992. Structural Geology. Macmillan. 
West R.G., 1980. The preglacial Pleistocene of the Norfolk and Suffolk coasts. Cambridge University Press, Cambridge.

West, R.G., 2000. Plant Life of the Quaternary Cold Stages. Cambridge University Press, Cambridge, UK. 320 pp.

Westaway, R. 2010. Improved age constraint for pre- and post-Anglian temperate-stage deposits in north Norfolk, UK, from analysis of serine decomposition in Bithynia opercula. Journal of Quaternary Science 25, 715-723.

Whiteman, C., 2002. Implications of a Middle Pleistocene Ice-wedge Cast at Trimingham, Norfolk, Eastern England. Permafrost and Periglacial Processes 13, 163170.

Van der Wateren, F.M., 1985. A model of glacial tectonics, applied to the ice-pushed ridges in the Central Netherlands. Geological Society of Denmark Bulletin 34, 55-74.

Van der Wateren, F.M., 1995. Structural geology and sedimentology of push moraines. Mededelingen Rijks Geologische Dienst Nr 54.

Van Gool, J.A., Kriegsman, L.M., Marker, M., Nichols, G.T., 1999. Thrust stacking in the inner Nordre Strømfjord area, West Greenland: significance for the tectonic evolution of the Palaeoproterozoic Nagssugtoqidian orogen. Precambrian Research 93, 71-86.

Vaughan-Hirsch, D.P., Phillips, E., Lee, J.R., Hart, J.K., 2013. Micromorphological analysis of poly-phase deformation associated with the transport and emplacement of glaciotectonic rafts at West Runton, north Norfolk, UK. Boreas 42, 376-394.

Table 1. Coleoptera species according to the nomenclature and taxonomic order of Lucht, 1987. Species now extinct in Britain are indicated by *. These specimens are accessioned in the geology collections of Norwich Castle Museum \& Art Gallery.

\begin{tabular}{|c|c|c|c|c|}
\hline Sample number & $\begin{array}{l}\text { Sample 1 } \\
\text { (Oct 2007) }\end{array}$ & $\begin{array}{l}\text { Sample 2 } \\
\text { (Feb 2010) }\end{array}$ & $\begin{array}{l}\text { Sample 3 } \\
\text { (March 2010) }\end{array}$ & $\begin{array}{l}\text { Sample } 4 \\
\text { (March 2010) }\end{array}$ \\
\hline \multicolumn{5}{|l|}{ Coleoptera } \\
\hline \multicolumn{5}{|l|}{ Carabidae } \\
\hline Carabus sp. & & & 1 & \\
\hline Pelophila borealis (Payk.) & 1 & & & \\
\hline Notiophilus of aquaticus. (L.) & 1 & 6 & & \\
\hline Dyschirius sp. & & 1 & & \\
\hline${ }^{*}$ Bembidion lapponicum Zett. & & 2 & & \\
\hline${ }^{\star}$ Bembidion velox (L.) & & 1 & & \\
\hline $\begin{array}{l}{ }^{*} \text { Bembidion cf fellmanni } \\
\text { Mannh. }\end{array}$ & 1 & 2 & & \\
\hline $\begin{array}{l}{ }^{*} \text { Pterostichus cf brevicornis } \\
\text { Kirby }\end{array}$ & & 1 & & \\
\hline Calathus sp. & & & 1 & \\
\hline Amara sp. & & & 1 & \\
\hline
\end{tabular}




\begin{tabular}{|c|c|c|c|c|}
\hline Dytiscidae & & & & \\
\hline Hydroporus palustris (L.) & & 1 & & \\
\hline $\begin{array}{l}\text { Potamonectes griseostriatus } \\
\text { (Geer,) }\end{array}$ & & 1 & 1 & \\
\hline llybius sp. & & 1 & & \\
\hline Hydraenidae & & & & \\
\hline Hydraena sp. & 2 & 1 & & \\
\hline Ochthebius kaninensis Popp. & & 1 & & \\
\hline $\begin{array}{l}{ }^{*} \text { Helophorus obscurellus } \\
\text { Popp. }\end{array}$ & 2 & 14 & & \\
\hline Helophorus nubilus F. & & 2 & & \\
\hline Helophorus cf aquaticus (L.) & 1 & & & \\
\hline${ }^{*}$ Helophorus glacialis Villa, & & 22 & & 2 \\
\hline Helophorus small spp. & & 2 & & \\
\hline Hydrophilidae & & & & \\
\hline Cercyon sp. & & 1 & 1 & \\
\hline Hydrobius fuscipes (L.) & & 2 & & \\
\hline Enochrus sp. & & 2 & & \\
\hline Silphidae & & & & \\
\hline Thanatophilus dispar (Hbst.) & 1 & & & \\
\hline Catopidae & & & & \\
\hline Catops sp. & & 1 & & \\
\hline Liodidae & & & & \\
\hline Agathidium sp. & & 1 & & \\
\hline Staphylinidae & & & & \\
\hline Olophrum fuscum Grav. & 1 & & & \\
\hline *Olophrum boreale Payk. & 1 & 1 & & \\
\hline $\begin{array}{l}\text { Eucnecosum brachypterum } \\
\text { (Grav.) }\end{array}$ & & 1 & & \\
\hline Oxytelus rugosus (F.) & & 1 & & \\
\hline Oxytelus nitidulus Grav. & & 2 & & \\
\hline Platystethus cornutus (Grav.) & & 1 & & \\
\hline $\begin{array}{l}\text { Platystethus nodifrons } \\
\text { Mannh. }\end{array}$ & & 1 & & \\
\hline Bledius sp. & & 1 & & \\
\hline Stenus juno (Payk.) & & & 1 & \\
\hline Stenus sp. & 1 & & & \\
\hline Tachinus sp. & & 1 & & \\
\hline Philonthus sp. & & 1 & & \\
\hline $\begin{array}{l}\text { Alaeocharinae Gen.et sp. } \\
\text { indet. }\end{array}$ & & 2 & 1 & \\
\hline Elateridae & & & & \\
\hline Hypnoidus riparius (F.) & & 1 & & \\
\hline Byrrhidae & & & & \\
\hline $\begin{array}{l}\text { *Simplocaria metallica } \\
\text { (Sturm, }\end{array}$ & & 1 & & \\
\hline Morychus sp. & & 1 & & \\
\hline Byrrhus arietinus Steff. & 1 & & & \\
\hline Coccinellidae & & & & \\
\hline${ }^{*}$ Hippodamia arctica Schneid. & & 2 & & \\
\hline Anthicidae & & & & \\
\hline${ }^{*}$ Anthicus ater (Panz.) & & 2 & & \\
\hline Scarabaeidae & & & & \\
\hline Aegialia sabuleti (Panz.) & 1 & 1 & & \\
\hline
\end{tabular}




\begin{tabular}{|l|r|r|r|l|}
\hline Aphodius sp. & 1 & & \\
\hline Chrysomelidae & 1 & 1 & & \\
\hline Plateumaris sericea (L.) & 1 & 1 & & \\
\hline Chrysomela sp. & & 6 & & \\
\hline Phyllodecta sp. & & 7 & 1 & \\
\hline Curculionidae & 1 & 1 & & \\
\hline Apion spp & 1 & 2 & & \\
\hline Otiorhynchus arcticus (F.) & & & & \\
\hline Otiorhynchus dubius (Ström,) & 2 & 7 & & \\
\hline Otiorhynchus rugifrons (Gyll.) & & & & \\
\hline Barynotus obscurus (F.) or & 1 & 1 & & \\
squamosus Germ. & 1 & & & \\
\hline Sitona spp. & 1 & & & \\
\hline Notaris bimaculatus (F.) & & & & \\
\hline Notaris aethiops (F.) & & & & \\
\hline Alophus triguttatus (F.) & & & & \\
\hline Hypera sp. & & & & \\
\hline
\end{tabular}

Table 2 Plant macrofossils identified from Sample 1 and their broadly associated environments.

\begin{tabular}{|l|l|l|l|}
\hline $\begin{array}{l}\text { Grassland \&/or bare } \\
\text { ground }\end{array}$ & $\begin{array}{l}\text { Waterside \& damp } \\
\text { ground }\end{array}$ & Aquatic & Unclassified taxa \\
\hline Plantago sp. & cf. Apium sp. & Potamogeton sp. & Carex sp. \\
\hline $\begin{array}{l}\text { Chenopodium } \\
\text { album type }\end{array}$ & Hippuris vulgaris & Nymphaea sp. & Chenopodium sp. \\
\hline cf. Polygonum sp. & Scirpus sp. & $\begin{array}{l}\text { Isoetes sp } \\
\text { (megaspore) }\end{array}$ & $\begin{array}{l}\text { Selaginella } \text { sp. } \\
\text { (megaspore) }\end{array}$ \\
\hline Ranunculus sp. & & & \\
\hline
\end{tabular}

Table 3 Pollen identified from Sample 2.

\begin{tabular}{|l|r|}
\hline Pollen taxa & Counts \\
\hline Betula & 4 \\
\hline Picea & 16 \\
\hline Pinus & 18 \\
\hline Quercus & 1 \\
\hline Corylus/Myrica type & 1 \\
\hline Salix & 2 \\
\hline Chenopodium type & 4 \\
\hline Cyperaceae & 6 \\
\hline Poaceae & 4 \\
\hline Sphagnum & 1 \\
\hline Pediastrum & 1 \\
\hline
\end{tabular}

